\title{
Mania and Stroke: A Systematic Review
}

\author{
Catarina O. Santos $^{\mathrm{a}}$ Lara Caeiro $^{\mathrm{a}}$ José M. Ferro ${ }^{\mathrm{b}}$ M. Luísa Figueira ${ }^{\mathrm{c}}$ \\ ${ }^{a}$ Institute of Molecular Medicine, Faculty of Medicine, University of Lisbon, ${ }^{b}$ Stroke Unit, Neurology Service and \\ 'Psychiatry Service, Department of Neurosciences, Hospital de Santa Maria, Faculty of Medicine, University of Lisbon, \\ Lisbon, Portugal
}

\section{Key Words}

Mania·Stroke

\begin{abstract}
Background: Mania is a rare consequence of stroke and according to the sparse published information it is difficult to describe its demographic, clinical and prognostic characteristics. Methods: We performed a systematic review of all cases of mania and stroke to describe those characteristics. Studies were identified from comprehensive searches of electronic databases, reference lists of the studies collected and handbooks. Two authors independently assessed abstracts, and collected and extracted data. Results: From 265 abstracts, 139 were potentially relevant. For the first analysis, which tries to answer the clinical question of the relationship between mania and stroke, 49 studies met the inclusion criteria and described 74 cases. For the second analysis, we looked for an explicit temporal and causal relationship between manic symptoms and stroke, and selected 32 studies describing 49 cases. In both analyses, the typical patient was male, without a personal or family history of psychiatric disorder, with at least one vascular risk factor, but without subcortical atrophy and had suffered a right cerebral infarct. The majority of patients (92\%) presented elevated mood as the first symptom. The other frequent symptoms were an increased rate or amount of speech (71\%), insomnia (69\%) and agitation (63\%). Conclusions: Post-stroke mania should be
\end{abstract}

considered in any manic patient who presents concomitant neurological focal deficits and is older than expected for the onset of primary mania. The results of a systematic study of mania in acute stroke with subsequent follow-up and data from diffusion MR or perfusion CT in a multicenter study with a central database would be relevant.

Copyright $\odot 2011$ S. Karger AG, Basel

\section{Introduction}

Mania is characterized by affective disturbances, such as an elevated, expansive or irritable mood, changes in speech, with an increased rate or amount, disturbances in language - thought and content, with flight of ideas, grandiose ideation and lack of insight and behavioural disturbances characterized by overactivity and social disinhibition [1-5]. In 1978, Krauthammer and Klerman [6] introduced the concept of secondary mania for mania caused by neurological, metabolic or toxic disorder.

Mania seems to be a rare consequence of stroke [4, 7-9], but there are few systematic studies of mania in acute stroke [10]. According to previous case reports, post-stroke mania has been related to: (1) predisposing genetic factor, (2) subcortical brain atrophy, and (3) damage to the right corticolimbic pathways [8-16]. Mania seems to be more frequent after right-sided lesions, but there are also reports of mania following left lesions $[7,17$,

\section{KARGER}

Fax +4161306 1234

E-Mail karger@karger.ch

www.karger.com
(C) 2011 S. Karger AG, Basel

$1015-9770 / 11 / 0321-0011 \$ 38.00 / 0$

Accessible online at:

www.karger.com/ced
Catarina O. Santos

Serviço de Neurologia (Piso 6), Centro de Estudos de Egas Moniz

Hospital de Santa Maria

PT-1649-035 Lisboa (Portugal)

Tel. +351 21795 7474, E-Mail acosta@fm.ul.pt 
18]. Based on the sparse published information, it is difficult to describe the demographic, clinical and prognostic characteristics of post-stroke mania. This systematic review of all cases of mania associated with stroke published until December 2010 tries to answer those questions and to increase the robustness of the evidence of this neuropsychiatric complication of stroke.

\section{Methods}

Search Strategy

Relevant articles on post-stroke mania cases were identified by electronic search of MEDLINE (until December 2010), by crossreferencing the following $\mathrm{MeSH}$ terms: 'bipolar disorder' and 'cerebrovascular disease' (online suppl. table 1; for all online suppl. material, see www.karger.com/doi/10.1159/000327032). We also ran the search in EMBASE and Web of Science databases and identified other cases and studies consulting the reference list of the studies collected and handbooks of neuropsychiatry of stroke. Two authors (C.O.S., J.M.F.) independently assessed all abstracts, and collected and extracted data.

\section{Inclusion Criteria}

The primary outcome was the presence of secondary mania after a stroke. For inclusion, studies were required to fulfil the following inclusion criteria: (1) all cases of mania and stroke, (2) patients with a diagnosis of cerebral infarct, intracerebral haemorrhage or subarachnoid haemorrhage, and (3) adult patients ( $\geq 18$ years old).

We performed two different analyses. In the first one, we included all cases of mania and stroke, even when the temporal or causal relationship (Appendix) between them was not explicit or did not exist. This analysis answers the clinical question of what relationship exists between mania and stroke.

In the second analysis, we looked for an explicit temporal and causal relationship between manic symptoms and stroke. Therefore, we applied DSM-IV-TR criteria of mood disorder due to acute stroke with manic features [1] and the criteria of secondary mania by Krauthammer and Klerman [6] (table 1).

\section{Exclusion Criteria}

Studies that met one of the following items were excluded from both analyses: (1) duplicate reports; (2) cases with unruptured aneurysms or subdural haematoma, and (3) cases with a diagnosis of bipolar disorder and/or manic episodes before the index stroke.

\section{Data Extraction}

The following general descriptive information was extracted from each study: (1) type of study: randomized controlled trial, cohort study, case-control study, case series or case report; (2) diagnosis, diagnostic criteria (DSM or ICD), type of assessment (clinical and/or mania scales) and interviewer (neurologist, psychiatrist, psychologist, nurse); (3) demography and past medical history: age, gender, years of education, personal and/or family history of psychiatric disorder and vascular risk factors; (4) symptoms and signs, onset, duration, description; (5) stroke: type, location and presence of subcortical atrophy on CT/MRI; (6) treat-
Table 1. Diagnostic criteria for post-stroke mania

1 DSM-IV-TR diagnostic criteria for 293.83 mood disorder due to stroke with manic features

A A prominent and persistent disturbance in mood predominates in the clinical picture and is characterized by elevated, expansive or irritable mood

B There is evidence from the history, physical examination, or laboratory findings that the disturbance is the direct physiological consequence of a stroke

C The disturbance is not accounted for by another mental disorder

D The disturbance does not occur exclusively during the course of a delirium

E The symptoms cause clinically significant distress or impairment in social, occupational, or other important areas of functioning

2 Krauthammer and Klerman [6] criteria for secondary mania

A Symptoms duration of at least 1 week

B Presence of elevated or irritable mood

C Presence of at least two of the following symptoms: hyperactivity, pressured speech, flight of ideas, grandiosity, decreased sleep, distractibility and lack of judgment

D There was no previous history of manic depressive or other affective illness and symptoms of a confusional state (such as delirium) co-occurring with the mania

ment: type and dosage, duration and efficacy of medication, and (7) outcome and follow-up, modified Rankin Scale score and recurrence of manic episodes. To assess the quality of included studies, we analysed data regarding the type of study, quality of assessment and clinical information provided.

\section{Results}

\section{Study Identification and Selection}

The review flow chart is shown in figure 1. From 265 abstracts, 139 were potentially relevant, of which 49 studies (35\%) met the inclusion criteria. These 49 studies describing 74 cases of post-stroke mania were included in the first analysis to determine the most important characteristics of those cases. In a second analysis, from those 49 studies we selected 32 studies (49 cases), corresponding to the more restricted criteria of post-stroke mania.

The majority of the studies were case reports $(71 \%)[7$, $8,17,19-25,27-30,32-41,43-49,56-58,60]$, followed by case series (14\%) $[16,18,26,31,51,53,54]$ and cohort studies $(8 \%)[12,42,52,61]$. The fact that case reports are usually shorter descriptions explains the lack of information we found when we tried to assess other parameters of the diagnosis and assessment. The cases came predominant- 
Fig. 1. Profile of the systematic review.

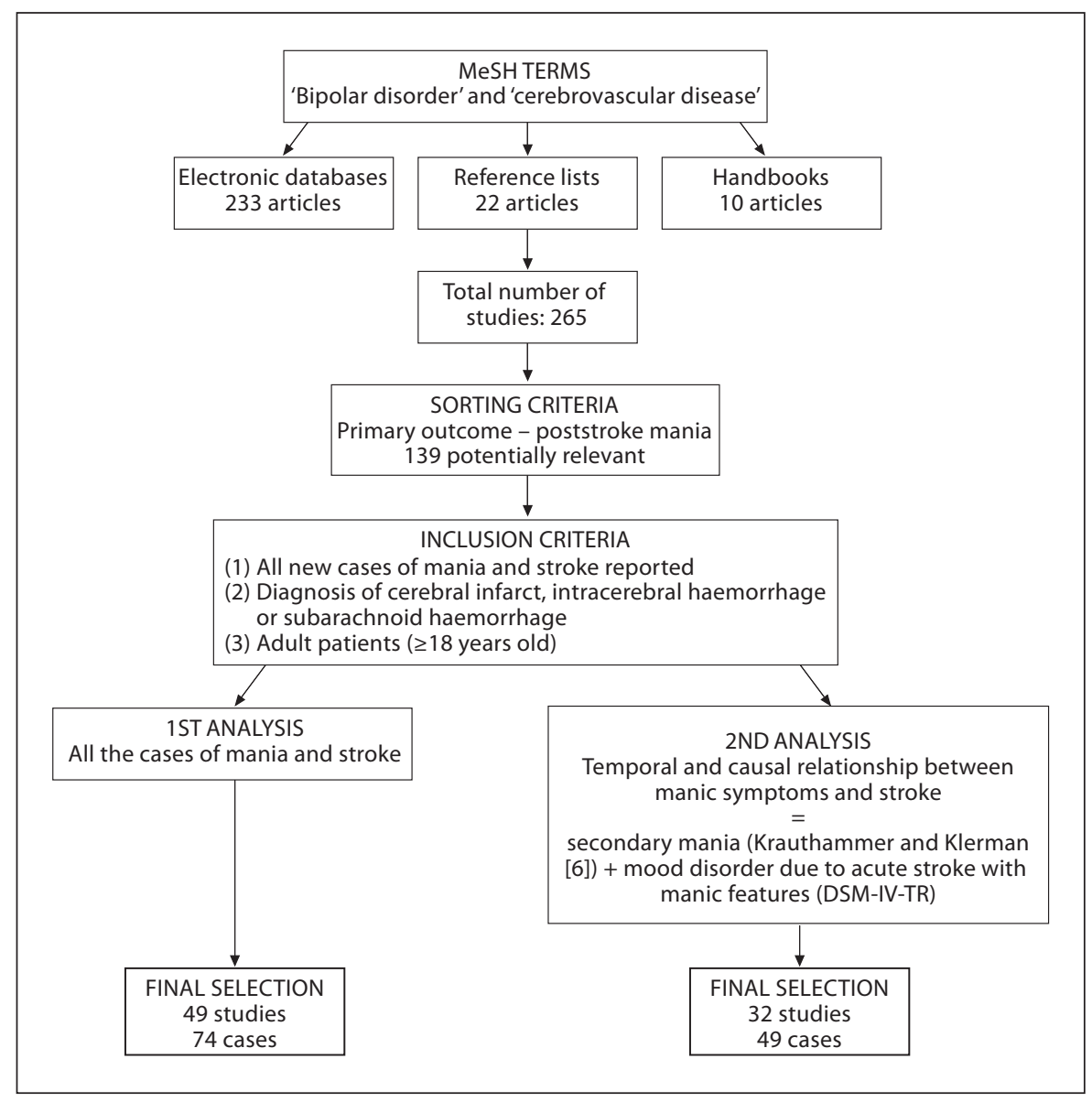

ly from psychiatric departments (61\%), although in many studies it was not explicit if patients were or were not hospitalized and in which department (table 2).

Table 3 shows the reason for the exclusion of 90 of the 139 potentially relevant studies (65\%) and their references. We excluded 12 patients from the group of Starkstein and colleagues $[9,10,13-15,128]$ because, although they were cases of stroke and mania, we have only group data.

\section{First Analysis - All Cases of Mania and Stroke}

In this first analysis, we included all cases of stroke and mania independently of the causal and temporal relationship between them.

Table 4 shows a summary of the main characteristics of the 74 cases included. Mania cases occurred in young and older stroke patients in a similar proportion ( $\mathrm{p}=$ 0.19 ). For the other variables, we found significant statistical differences. The typical patient was male, without a personal or family history of psychiatric disorder, with at least one vascular risk factor, but without subcortical atrophy and had suffered a right cerebral infarct.

In 49 of the 74 cases, we could find a temporal and causal relationship between stroke and mania. In another 4 cases, mania occurred concomitantly with a change or initiation of a treatment which might cause mania in stroke patients with different evolution time periods. Four patients had had a previous affective disorder; 3 had depression [20, 28, 30] and 1 cyclothymia [8]. In 17 cases, we could not determine the relationship between stroke and mania.

\section{Second Analysis - Cases of Secondary Mania}

When we only included the 49 patients with poststroke mania, we found similar results to those obtained in the first analysis (table 5). The typical patient with post-stroke mania was male, without a personal or family history of psychiatric disorder, with at least one vascular risk factor, without subcortical atrophy and had suffered a right cerebral infarct. In all those cases, there 
Table 2. Characteristics of included studies

\begin{tabular}{|c|c|c|}
\hline Studies characteristics & $\begin{array}{l}\text { Number of } \\
\text { studies }(\mathrm{n}=49)\end{array}$ & References \\
\hline \multicolumn{3}{|l|}{ Type of study } \\
\hline Randomized controlled trial & 0 & - \\
\hline Cohort study & 4 & $12,42,52,61$ \\
\hline Case-control study & 0 & - \\
\hline Case series & 7 & $16,18,26,31,51,53,54$ \\
\hline Case report & 35 & $7,8,17,19-25,27-30,32-41,43-49,56-58,60$ \\
\hline Retrospective & 3 & $50,55,59$ \\
\hline \multicolumn{3}{|l|}{ Department } \\
\hline Neurology & 14 & $16,29,34,38-41,44,46,47,51,54,57,61$ \\
\hline Psychiatry & 30 & $7,8,12,17-25,27,28,30-32,35-37,42,43,45,48,50,52,55,58,59,60$ \\
\hline Both & 3 & $33,53,56$ \\
\hline Other & 1 & 26 \\
\hline Not specified & 1 & 49 \\
\hline \multicolumn{3}{|l|}{ Diagnosis } \\
\hline DSM criteria & 17 & $12,16,17,20,22-26,34,38,39,43,44,46,52,61$ \\
\hline ICD criteria & 3 & $8,27,50$ \\
\hline Krauthammer and Klerman & 3 & $18,19,58$ \\
\hline Not specified & 26 & $7,21,28-33,35-37,40-42,45,47-49,51,53-57,59,60$ \\
\hline \multicolumn{3}{|l|}{ Type of assessment } \\
\hline Clinical & 27 & $7,8,16-18,20-22,24,26,30-32,34,35,37,38,40,42,43,45,48,53,54,57,58,60$ \\
\hline Scale & 0 & - \\
\hline Both & 17 & $12,19,23,25,27,28,29,33,36,39,41,44,46,47,52,56,61$ \\
\hline Not specified & 5 & $49-51,55,59$ \\
\hline \multicolumn{3}{|l|}{ Interviewer } \\
\hline Medical doctor & 1 & 41 \\
\hline Psychiatrist & 9 & $12,22,23,29,31,38,43,52,60$ \\
\hline Psychologist & 1 & 61 \\
\hline Nurse & 0 & - \\
\hline Not specified & 38 & $7,8,16-19,20,21,24-28,30,32-37,39,40,42,44-51,53-59$ \\
\hline
\end{tabular}

seemed to be a clear temporal and causal relationship between stroke and mania. The majority of mania cases appeared in the first days after stroke, with $53 \%$ immediately after stroke, $23 \%$ during the first month after stroke and $23 \%$ after this first month. In the online supplementary table 2, we present the description of each case.

Table 6 describes the symptoms of mania in those 49 cases. The majority of patients (92\%) presented elevated mood as the first symptom. Forty-one percent of patients $(\mathrm{n}=20)$ alternated between elevated and irritable mood and only $8 \%$ presented irritability only. The other frequent symptoms were an increased rate or amount of speech (71\%), insomnia (69\%) and agitation (63\%). We counted the number of core symptoms of mania and the majority of patients presented 5 or more symptoms of mania (31\% 5-6 symptoms and $27 \% \geq 7$ symptoms).
Considering the patients for whom we had information, in the majority of these cases mania lasted between 1 and 12 weeks, more frequently without recurrence or minor symptoms (hypomania).

\section{Treatment of Secondary Mania}

Of the 74 cases, we have data on the treatment for only 47 cases (64\%). Mood stabilizers (lithium, carbamazepine and valproic acid) were used in 62\%, typical antipsychotics (haloperidol) in 32\%, atypical antipsychotics (olanzapine, risperidone) in 19\% and benzodiazepines (diazepam, lorazepam) in 13\%. Data on dosages, duration of the treatment and efficacy were so scarce that it was impossible to provide any meaningful results. 
Table 3. Excluded studies

\begin{tabular}{llll}
\hline Criteria & Description & $\begin{array}{l}\text { Number of } \\
\text { studies }(\mathrm{n}=90)\end{array}$ & References \\
\hline Duplicated reports & $\begin{array}{l}\text { Revisions } \\
\text { Description of not new cases }\end{array}$ & $32(36 \%)$ & $\begin{array}{l}9-11,13-15,62,64,68-71,78,80,88,93,98,99,101- \\
104,107,109,110,112,114,117,125,128,132,137\end{array}$ \\
\hline No stroke & $\begin{array}{l}\text { Aneurisms unruptured } \\
\text { Subdural haematoma } \\
\text { No stroke }\end{array}$ & $19(21 \%)$ & $63,65,72,73,77,79,81,84,86,100,106,121,124$, \\
& Bipolar disorder & $32(36 \%)$ & $5,66,67,74-76,82,83,85,87,89,91,92,94,95,97$, \\
Previous affective & Mania & $105,108,113,115,116,118,120,122,123,127,129$, \\
disorder & Other neuropsychiatric disturbances & & $134,136,138,140,141$ \\
\hline Studies not found & $\begin{array}{l}\text { Articles not available and contact } \\
\text { with authors impossible }\end{array}$ & $7(7 \%)$ & $90,96,111,119,139,143,144$ \\
& & & \\
\hline
\end{tabular}

\section{Discussion}

This systematic review confirms the rarity of poststroke mania because in about 50 years we found only 74 reported cases of adult stroke patients with mania symptoms. Robinson et al. [10] and Dunne et al. [145] identified only 3 cases of post-stroke mania in a series of 700 and 661 consecutive stroke patients, respectively. Among 188 consecutive acute stroke patients, our group found 3 (1.6\%) cases of mania [61]. Although mania can be very disrupting during hospitalization and recovery, its low prevalence limits the description of clinical, demographic and prognostic features and the identification of evidence-based strategies for dealing with it.

We found a typical patient to be male, without a personal/family history of psychiatric disorder, with at least one vascular risk factor, without subcortical atrophy and with a right cerebral infarct. Our results support previous research which concludes that there is a significant relationship between post-stroke mania and right hemispheric lesions causing a dysfunction in the ventral limbic circuit that involves the right orbitofrontal and basotemporal cortices, dorsomedial thalamic nucleus and head of the caudate nucleus $[10,16,27,78,80]$. The orbitofrontal circuit is a complex functional network that includes the orbitofrontal cortex, the basotemporal region, the thalamus and the caudate nucleus and is a central circuit in mood regulation and social behaviour $[16,33]$.

Establishing a causal relationship between stroke and mania has also been based on other factors than right lesions. The lack of a previous personal or family psychiatric affective disorder, the presence of vascular risk factors and a temporal relationship between the vascular event and the mood change in the absence of other potential precipitants of mania reinforce this etiological relationship [29, 30]. Also, if we look at the age range and average age of the included cases, we see that the onset of mania occurs much later in life than what is characteristic of primary mania.

Robinson and colleagues $[10,15]$ suggested that mania was associated with a genetic predisposition and/or subcortical atrophy. This was not supported by the present systematic review because in the majority of post-stroke mania cases we did not find a family or personal history of psychiatric disorder or subcortical atrophy. Krauthammer and Klerman [6] excluded patients with previous affective disorder in the diagnosis of secondary mania. In an epidemiological study about geriatric mania, the authors found that the majority of patients did not have a personal or family history of affective disorder [146]. We could not detect a significant role of subcortical atrophy.

The temporal relationship between stroke and mania ranged from immediately after stroke to up to 2 years thereafter [14].

The clinical profile of post-stroke mania is very similar to primary mania, characterized mainly by elevated mood/euphoria, pressured speech, flight of ideas, grandiosity and insomnia $[9,16,17,30,46,57]$. Starkstein et al. [15] did not find significant differences in the frequency of these symptoms in secondary and primary mania patients.

The follow-up of these patients was described in a minority of cases and some of these had recurrence of mania or presented hypomania. We could not confirm that about $30 \%$ of patients may develop a bipolar disorder [10]. 
Table 4. Description of the 74 cases of stroke and mania

\begin{tabular}{|c|c|c|}
\hline Variables & $\begin{array}{l}\text { Cases } \\
(n=63)\end{array}$ & $\mathrm{p}$ \\
\hline \multicolumn{3}{|l|}{ Age } \\
\hline$<65$ & 35 & $0.19^{\mathrm{a}}$ \\
\hline$\geq 65$ & 22 & \\
\hline Range & $27-91$ & \\
\hline No information & 17 & \\
\hline \multicolumn{3}{|l|}{ Gender } \\
\hline Female & 17 & $0.00^{\mathrm{a}}$ \\
\hline Male & 44 & \\
\hline No information & 13 & \\
\hline \multicolumn{3}{|l|}{ History of personal psychiatric disorder } \\
\hline Yes & 4 & $0.00^{\mathrm{a}}$ \\
\hline No & 55 & \\
\hline No information & 15 & \\
\hline \multicolumn{3}{|l|}{ Family history of psychiatric disorder } \\
\hline Yes & 3 & $0.00^{\mathrm{a}}$ \\
\hline No & 38 & \\
\hline No information & 33 & \\
\hline \multicolumn{3}{|l|}{ Vascular risk factors } \\
\hline Yes & 26 & $0.00^{\mathrm{a}}$ \\
\hline No & 7 & \\
\hline No information & 41 & \\
\hline \multicolumn{3}{|l|}{ Stroke type } \\
\hline Cerebral infarct & 56 & $0.00^{\mathrm{b}}$ \\
\hline Intracerebral haemorrhage & 7 & \\
\hline Subarachnoid haemorrhage & 9 & \\
\hline No information & 2 & \\
\hline \multicolumn{3}{|l|}{ Stroke laterality } \\
\hline Right & 50 & $0.00^{\mathrm{b}}$ \\
\hline Left & 11 & \\
\hline Bilateral & 4 & \\
\hline No information & 9 & \\
\hline \multicolumn{3}{|l|}{ Subcortical atrophy } \\
\hline Yes & 2 & $0.00^{\mathrm{a}}$ \\
\hline No & 36 & \\
\hline No information & 36 & \\
\hline \multicolumn{3}{|l|}{ Relation with stroke } \\
\hline Causal and temporal relationship & 49 & $0.00^{\mathrm{b}}$ \\
\hline Secondary to treatment & 4 & \\
\hline Previous affective disorder ${ }^{c}$ & 4 & \\
\hline Unknown & 17 & \\
\hline
\end{tabular}

a Binomial test for proportions.

${ }^{\mathrm{b}} \chi^{2}$ test for proportions.

${ }^{c}$ Three cases of depression and one case of cyclothymia.

A variety of psychotropic drugs have been used to treat post-stroke mania, mainly mood stabilizers, typical antipsychotics and atypical antipsychotics with variable outcome $[11,27,30,78]$. Lithium was frequently used with favourable results, but its use is controversial in cases with
Table 5. Description of the 49 cases of stroke and mania

\begin{tabular}{|c|c|c|}
\hline Variables & $\begin{array}{l}\text { Cases } \\
(\mathrm{n}=45)\end{array}$ & $\mathrm{p}$ \\
\hline \multicolumn{3}{|l|}{ Age } \\
\hline$<65$ & 25 & $0.05^{\mathrm{a}}$ \\
\hline$\geq 65$ & 11 & \\
\hline Range & $27-81$ & \\
\hline No information & 13 & \\
\hline \multicolumn{3}{|l|}{ Gender } \\
\hline Female & 11 & $0.01^{\mathrm{a}}$ \\
\hline Male & 28 & \\
\hline No information & 10 & \\
\hline \multicolumn{3}{|c|}{ History of personal psychiatric disorder } \\
\hline Yes & 1 & $0.00^{\mathrm{a}}$ \\
\hline No & 47 & \\
\hline No information & 1 & \\
\hline \multicolumn{3}{|c|}{ Family history of psychiatric disorder } \\
\hline Yes & 2 & $0.00^{\mathrm{a}}$ \\
\hline No & 29 & \\
\hline No information & 18 & \\
\hline \multicolumn{3}{|l|}{ Vascular risk factors } \\
\hline Yes & 20 & $0.02^{\mathrm{a}}$ \\
\hline No & 7 & \\
\hline No information & 22 & \\
\hline \multicolumn{3}{|l|}{ Stroke type } \\
\hline Cerebral infarct & 36 & $0.00^{\mathrm{b}}$ \\
\hline Intracerebral haemorrhage & 6 & \\
\hline Subarachnoid haemorrhage & 7 & \\
\hline No information & 0 & \\
\hline \multicolumn{3}{|l|}{ Stroke laterality } \\
\hline Right & 39 & $0.00^{\mathrm{b}}$ \\
\hline Left & 7 & \\
\hline Bilateral & 3 & \\
\hline No information & 0 & \\
\hline \multicolumn{3}{|l|}{ Subcortical atrophy } \\
\hline Yes & 0 & $0.00^{\mathrm{a}}$ \\
\hline No & 29 & \\
\hline No information & 20 & \\
\hline $\begin{array}{l}{ }^{\mathrm{a}} \text { Binomial test for proportic } \\
{ }^{\mathrm{b}} \chi^{2} \text { test for proportions. }\end{array}$ & & \\
\hline
\end{tabular}

cerebral lesions $[16,60]$. Antipsychotics were used in cases of severe mania with psychotic symptoms, and throughout all these years atypical antipsychotics have been preferred because they have comparatively minor side effects. Benzodiazepines were also used as adjunctive treatment for hyperactivity and insomnia [32]. These drugs should be given to post-stroke mania patients with caution for two main reasons: first because older patients have a high sensitivity to psychotropic drugs and second because the presence of stroke itself could change their efficacy [114]. 
Table 6. Symptoms of mania in 49 cases of stroke and mania

\begin{tabular}{|c|c|c|c|c|c|c|c|c|c|c|c|c|c|}
\hline Ref. & Elation & $\begin{array}{l}\text { Irrita- } \\
\text { bility }\end{array}$ & $\begin{array}{l}\text { Hyper- } \\
\text { activity }\end{array}$ & $\begin{array}{l}\text { Talk- } \\
\text { ativeness }\end{array}$ & $\begin{array}{l}\text { Distract- } \\
\text { ibility }\end{array}$ & $\begin{array}{l}\text { Flight } \\
\text { of ideas }\end{array}$ & $\begin{array}{l}\text { Gran- } \\
\text { diosity }\end{array}$ & $\begin{array}{l}\text { Sleep- } \\
\text { lessness }\end{array}$ & Denial & $\begin{array}{l}\text { Symp- } \\
\text { toms, n }\end{array}$ & $\begin{array}{l}\text { Duration } \\
\text { weeks }\end{array}$ & $\begin{array}{l}\text { Follow- } \\
\text { up }\end{array}$ & Recurrence \\
\hline 19 & $\mathrm{x}$ & & & & & & $\mathrm{x}$ & $\mathrm{x}$ & & 3 & 12 & & \\
\hline 24 & $\mathrm{x}$ & $\mathrm{x}$ & $\mathrm{x}$ & & $\mathrm{x}$ & $\mathrm{x}$ & & $\mathrm{x}$ & $\mathrm{x}$ & 7 & & & \\
\hline 25 & $\mathrm{x}$ & $\mathrm{x}$ & $\mathrm{x}$ & $\mathrm{x}$ & $\mathrm{x}$ & & $\mathrm{x}$ & $\mathrm{x}$ & $\mathrm{x}$ & 8 & 8 & $\mathrm{y}$ & $\mathrm{n}$ \\
\hline 26 & $\mathrm{x}$ & $\mathrm{x}$ & $\mathrm{x}$ & $\mathrm{x}$ & & $\mathrm{x}$ & & $\mathrm{x}$ & & 6 & & $\mathrm{y}$ & hypomania \\
\hline 26 & $\mathrm{x}$ & $\mathrm{x}$ & $\mathrm{x}$ & $\mathrm{x}$ & & & & $\mathrm{x}$ & $\mathrm{x}$ & 6 & & & \\
\hline 27 & $\mathrm{x}$ & $\mathrm{x}$ & $\mathrm{x}$ & $\mathrm{x}$ & $\mathrm{x}$ & & & & $\mathrm{x}$ & 6 & 12 & $y$ & $\mathrm{n}$ \\
\hline 29 & $\mathrm{x}$ & & $\mathrm{x}$ & $\mathrm{x}$ & & $\mathrm{x}$ & $\mathrm{x}$ & $\mathrm{x}$ & & 6 & 4 & $\mathrm{y}$ & hypomania \\
\hline 31 & $\mathrm{x}$ & $\mathrm{x}$ & $\mathrm{x}$ & $\mathrm{x}$ & & & & $\mathrm{x}$ & $\mathrm{x}$ & 6 & & & \\
\hline 32 & $\mathrm{x}$ & $\mathrm{x}$ & $\mathrm{x}$ & $\mathrm{x}$ & $\mathrm{x}$ & $\mathrm{x}$ & $\mathrm{x}$ & $\mathrm{x}$ & $\mathrm{x}$ & 9 & & & \\
\hline 33 & $\mathrm{x}$ & & $\mathrm{x}$ & $\mathrm{x}$ & $\mathrm{x}$ & $\mathrm{x}$ & & $\mathrm{x}$ & $\mathrm{x}$ & 7 & 8 & $\mathrm{y}$ & hypomania \\
\hline 34 & $\mathrm{x}$ & & $\mathrm{x}$ & $\mathrm{x}$ & $\mathrm{x}$ & $\mathrm{x}$ & & $\mathrm{x}$ & $\mathrm{x}$ & 7 & 8 & & \\
\hline 36 & $\mathrm{x}$ & & & $\mathrm{x}$ & & & & & $\mathrm{x}$ & 3 & 10 & $\mathrm{y}$ & $\mathrm{y}$ \\
\hline 7 & $\mathrm{x}$ & $\mathrm{x}$ & $\mathrm{x}$ & $\mathrm{x}$ & $\mathrm{x}$ & $\mathrm{x}$ & & $\mathrm{x}$ & & 7 & 8 & $\mathrm{y}$ & $\mathrm{n}$ \\
\hline 38 & $\mathrm{x}$ & $\mathrm{x}$ & $\mathrm{x}$ & $\mathrm{x}$ & & $\mathrm{x}$ & $\mathrm{x}$ & $\mathrm{x}$ & $\mathrm{x}$ & 8 & & & \\
\hline 17 & $\mathrm{x}$ & $\mathrm{x}$ & $\mathrm{x}$ & $\mathrm{x}$ & & $\mathrm{x}$ & $\mathrm{x}$ & $\mathrm{x}$ & & 7 & 8 & & \\
\hline 40 & $\mathrm{x}$ & & & $\mathrm{x}$ & & & & $\mathrm{x}$ & & 3 & 8 & & $\mathrm{n}$ \\
\hline 41 & $\mathrm{x}$ & & $\mathrm{x}$ & $\mathrm{x}$ & & & & $\mathrm{x}$ & & 4 & 4 & & \\
\hline 43 & $\mathrm{x}$ & $\mathrm{x}$ & $\mathrm{x}$ & $\mathrm{x}$ & & $\mathrm{x}$ & $\mathrm{x}$ & & & 6 & 38 & & \\
\hline 45 & $\mathrm{x}$ & $\mathrm{x}$ & $\mathrm{x}$ & $\mathrm{x}$ & & & $\mathrm{x}$ & $\mathrm{x}$ & & 6 & & & \\
\hline 46 & $\mathrm{x}$ & & & $\mathrm{x}$ & $\mathrm{x}$ & $\mathrm{x}$ & $\mathrm{x}$ & $\mathrm{x}$ & $\mathrm{x}$ & 7 & $4-8$ & $y$ & $\mathrm{n}$ \\
\hline 47 & $\mathrm{x}$ & $\mathrm{x}$ & $\mathrm{x}$ & $\mathrm{x}$ & $\mathrm{x}$ & $\mathrm{x}$ & & & & 6 & 52 & & \\
\hline$\overline{48}$ & $\mathrm{x}$ & $\mathrm{x}$ & $\mathrm{x}$ & $\mathrm{x}$ & $\mathrm{x}$ & $\mathrm{x}$ & & $\mathrm{x}$ & & 7 & cyclic & $y$ & $\mathrm{n}$ \\
\hline 12 & $\mathrm{x}$ & & & & & & & $\mathrm{x}$ & & & & & \\
\hline 12 & $\mathrm{x}$ & & & & & & & $\mathrm{x}$ & & & & & \\
\hline 12 & $\mathrm{x}$ & & & & & & & $\mathrm{x}$ & & & & & \\
\hline 12 & $\mathrm{x}$ & & & & & & & $\mathrm{x}$ & & & & & \\
\hline 12 & $\mathrm{x}$ & & & & & & & $\mathrm{x}$ & & & & & \\
\hline 12 & $\mathrm{x}$ & & & & & & & $\mathrm{x}$ & & & & & \\
\hline 12 & $\mathrm{x}$ & & & & & & & & & & & & \\
\hline 12 & $\mathrm{x}$ & & & & & & & & & & & & \\
\hline 12 & $\mathrm{x}$ & & & & & & & & & & & & \\
\hline 12 & $\mathrm{x}$ & & & & & & & & & & & & \\
\hline 51 & & $\mathrm{x}$ & $\mathrm{x}$ & & & & $\mathrm{x}$ & $\mathrm{x}$ & & 4 & & $y$ & $\mathrm{n}$ \\
\hline 51 & & $\mathrm{x}$ & $\mathrm{x}$ & & & & $\mathrm{x}$ & $\mathrm{x}$ & & 4 & & $\mathrm{y}$ & $\mathrm{n}$ \\
\hline 52 & $\mathrm{x}$ & & $\mathrm{x}$ & $\mathrm{x}$ & $\mathrm{x}$ & & $\mathrm{x}$ & $\mathrm{x}$ & & 6 & & & \\
\hline 52 & $\mathrm{x}$ & & $\mathrm{x}$ & $\mathrm{x}$ & & $\mathrm{x}$ & $\mathrm{x}$ & $\mathrm{x}$ & & 6 & & $\mathrm{y}$ & $y$ \\
\hline 52 & $\mathrm{x}$ & & & $\mathrm{x}$ & & & $\mathrm{x}$ & & & 3 & & & \\
\hline 52 & $\mathrm{x}$ & & & $\mathrm{x}$ & & & $\mathrm{x}$ & & & 3 & & & \\
\hline 52 & $\mathrm{x}$ & & & $\mathrm{x}$ & & & $\mathrm{x}$ & & & 3 & & & \\
\hline 53 & & $\mathrm{x}$ & $\mathrm{x}$ & $\mathrm{x}$ & & & & $\mathrm{x}$ & & 4 & cyclic & & \\
\hline 56 & $\mathrm{x}$ & $\mathrm{x}$ & $\mathrm{x}$ & $\mathrm{x}$ & & $\mathrm{x}$ & $\mathrm{x}$ & & & 6 & & $\mathrm{y}$ & $\mathrm{y}$ \\
\hline 57 & $\mathrm{x}$ & & & $\mathrm{x}$ & & $\mathrm{x}$ & & & & 3 & 8 & $\mathrm{y}$ & $\mathrm{n}$ \\
\hline 16 & $\mathrm{x}$ & $\mathrm{x}$ & $\mathrm{x}$ & $\mathrm{x}$ & & & & $\mathrm{x}$ & $\mathrm{x}$ & 6 & 4 & & $\mathrm{n}$ \\
\hline 16 & $\mathrm{x}$ & $\mathrm{x}$ & $\mathrm{x}$ & $\mathrm{x}$ & & $\mathrm{x}$ & & $\mathrm{x}$ & $\mathrm{x}$ & 7 & 6 & $\mathrm{y}$ & $\mathrm{y}$ \\
\hline 18 & $\mathrm{x}$ & $\mathrm{x}$ & $\mathrm{x}$ & $\mathrm{x}$ & & $\mathrm{x}$ & $\mathrm{x}$ & $\mathrm{x}$ & & 7 & & & \\
\hline 18 & & $\mathrm{x}$ & $\mathrm{x}$ & $\mathrm{x}$ & $\mathrm{x}$ & $\mathrm{x}$ & & & & 5 & & & \\
\hline 58 & $\mathrm{x}$ & $\mathrm{x}$ & $\mathrm{x}$ & $\mathrm{x}$ & & $\mathrm{x}$ & & $\mathrm{x}$ & & 6 & cyclic & $y$ & $\mathrm{y}$ \\
\hline 60 & $\mathrm{x}$ & & $\mathrm{x}$ & $\mathrm{x}$ & & & $\mathrm{x}$ & & $\mathrm{x}$ & 5 & cyclic & $\mathrm{y}$ & $\mathrm{y}$ \\
\hline 61 & $\mathrm{x}$ & $\mathrm{x}$ & $\mathrm{x}$ & $\mathrm{x}$ & $\mathrm{x}$ & $\mathrm{x}$ & $\mathrm{x}$ & $\mathrm{x}$ & $\mathrm{x}$ & 9 & 2 & $\mathrm{y}$ & $\mathrm{n}$ \\
\hline Total & 45 & 24 & 31 & 35 & 13 & 21 & 20 & 34 & 15 & & & 18 & 9 \\
\hline
\end{tabular}


The lack of placebo-controlled and double-blind trials and the differences in efficacy between the same or similar drugs in different cases reinforces doubts about the role of pharmacological treatment and impedes the definition of targeted and evidence-based treatment guidelines $[2,16,32,114]$.

This systematic review had some limitations caused essentially by the nature of the studies. Case studies and case series are shorter reports and the authors referred only to what they considered to be the more relevant data about the case. So, we have a significant proportion of missing data on important variables. In many cases, we did not know if the missing information was not assessed or if it was only omitted. We have reviewed reports since 1960 , and over the years the definition of what could be important to assess and report has changed. The assessment methods, psychological tests and imagiological techniques improved markedly over time. Case reports also vary in many variables, such as diagnostic criteria, methods of assessment, treatment and follow-up. Moreover, we cannot exclude that there were other cases not published that were presented at congresses and other meetings and even others that were underdiagnosed in the context of a sudden and serious disease such as stroke, specially in cases with major symptoms like aphasia. Finally, a publication bias could exist favouring the dissemination of positive cases and not others. Moreover, since right-sided lesion cases have been published, more attention may have been devoted to the presence and diagnosis of manic symptoms in these patients.
In conclusion, post-stroke mania should be considered in any manic patient who presents concomitant neurological focal deficits and is older than expected for the onset of primary mania. More frequently, these patients were male, without psychiatric antecedents or subcortical atrophy, with vascular risk factors and right infarct. Although rare, the results of a systematic study of mania in acute stroke with follow-up and data from diffusion MR or perfusion CT in a multicenter study with a central database would be relevant.

\section{Appendix}

Temporal or causal relationship = there is evidence from historical data, physical examination, or laboratory findings that manic symptoms are a direct physiological consequence of a stroke, occurring immediately or up to 3 years thereafter.

History of personal psychiatric disorder = previous psychiatric disorder was diagnosed if the patient had at least once in his/her lifetime been treated for a psychiatric disorder and specific medication for this condition had been prescribed for more than a month.

Family history of psychiatric disorder = presence of psychiatric disorder diagnosed in family relatives.

Vascular risk factors = includes hypertension, diabetes mellitus, hyperlipidaemias, myocardial infarction, angina pectoris, heart failure, atrial fibrillation, lower limb arteriopathy and peripheral vascular disease, history of stroke and/or transient ischaemic attack; cigarette smoking and alcohol consumption.

\section{References}

1 American Psychiatric Association: Mood disorders; in: Diagnostic and Statistical Manual of Mental Disorders, ed 4, text revision. Washington, American Psychiatric Association, 2002, pp 345-428.

$\checkmark 2$ Ferro JM, Caeiro L, Santos C: Poststroke emotional and behavior impairment: a narrative review. Cerebrovasc Dis 2009;27(suppl 1):197-203.

3 Sadock BJ, Sadock VA: Mood disorders; in Sadock BJ, Sadock VA (eds): Kaplan and Sadock's Synopsis of Psychiatry. Behavioural Sciences/Clinical Psychiatry, ed 9. Philadelphia, Lippincott Williams \& Wilkins, 2003, pp 534-572.

4 Starkstein SE, Manes F: Mania and maniclike disorders; in Bogousslavsky J, Cummings JL (eds): Behaviour and Mood Disorders in Focal Brain Lesions. Cambridge, Cambridge University Press, 2000, pp 6594.
5 Vuilleumier P, Ghika-Schmid F, Bogousslavsky J, Assal G, Regli F: Persistent recurrence of hypomania and prosoaffective agnosia in a patient with right thala mic infarct. Neuropsychiatry Neuropsychol Behav Neurol 1998;11:40-44.

6 Krauthammer C, Klerman G: Secondary mania. Manic syndromes associated with antecedent physical illness or drugs. Arch Gen Psychiatry 1978;35:1333-1339.

$\checkmark 7$ Fenn D, George K: Post-stroke mania late in life involving the left hemisphere. Aust NZ J Psychiatry 1999;33:598-600.

8 Kumar S, Jacobson RR, Sathananthan K: Seasonal cyclothymia to seasonal bipolar affective disorder: a double switch after stroke. J Neurol Neurosurg Psychiatry 1997;63:796797.

-9 Starkstein SE, Robinson RG: Affective disorders and cerebral vascular disease. Br J Psychiatry 1989;154:170-182.
10 Robinson RG, Boston JD, Starkstein SE, Price TR: Comparison of mania and depression after brain injury: causal factors. Am J Psychiatry 1988;145:172-178.

11 Robinson RG: Mood disorders secondary to stroke. Semin Clin Neuropsychiatry 1997;2: 244-251.

12 Starkstein SE, Fedoroff P, Berthier ML, Robinson RG: Manic-depressive and pure manic states after brain lesions. Biol Psychiatry 1991;29:149-158.

13 Robinson RG, Starkstein SE: Mood disorders following stroke: new findings and future directions. J Geriatr Psychiatry 1989;22:1-15.

14 Starkstein SE, Boston JD, Robinson RG: Mechanisms of mania after brain injury. 12 case reports and review of the literature. J Nerv Ment Dis 1988;176:87-100. 
-15 Starkstein SE, Pearlson GD, Boston JD, Robinson RG: Mania after brain injury. A controlled study of causative factors. Arch Neurol 1987;44:1069-1073.

16 Cummings JL, Mendez MF: Secondary mania with focal cerebrovascular lesions. Am J Psychiatry 1984;141:1084-1087.

17 Liu CY, Wang SJ, Fuh JL, Yang YY, Liu HC: Bipolar disorder following a stroke involving the left hemisphere. Aust NZ J Psychiatry 1996;30:688-691.

- 18 Jampala VC, Abrams R: Mania secondary to left and right hemisphere damage. Am J Psychiatry 1983;140:1197-1199.

- 19 Semiz M, Kavakçı O, Yontar G, Yıldırım O: Case of organic mania associated with stroke and open heart surgery. Psychiatry Clin Neurosci 2010;64:587.

-20 Duggal HS, Singh I: New-onset vascular mania in a patient with chronic depression. Neuropsychiatry Clin Neurosci 2009;21: 480-482.

-21 López JD, Araúxo A, Páramo M: Late-onset bipolar disorder following right thalamic injury. Actas Esp Psiquiatr 2009;37:233-235.

22 Havle N, Ilnem MC, Yener F, Dayan C: Secondary mania after brain stem infarct Anadolu Psikiyatri Dergisi 2009;10:163-164.

$\checkmark 23$ Rocha FF, Carneiro JG, Pereira Pde A, Correa $\mathrm{H}$, Teixeira AL: Poststroke manic symptoms: an unusual neuropsychiatric condition. Rev Bras Psiquiatr 2008;30:173-174.

24 Dervaux A, Levasseur M: Risperidone and valproate for mania following stroke. J Neuropsychiatry Clin Neurosci 2008;20:247.

-25 da Rocha FF, Correa H, Teixeira AL: A successful outcome with valproic acid in a case of mania secondary to stroke of the right frontal lobe. Prog Neuropsychopharmacol Biol Psychiatry 2008;32:587-588.

-26 Nagaratnam N, Wong KK, Patel I: Secondary mania of vascular origin in elderly patients: a report of two clinical cases. Arch Gerontol Geriatr 2006;43:223-232.

-27 Goyal R, Sameer M, Chandrasekaran R: Mania secondary to right-sided stroke-responsive to olanzapine. Gen Hosp Psychiatry 2006;28:262-263

28 Mimura M, Nakagome K, Hirashima N, et al: Left frontotemporal hyperperfusion in a patient with post-stroke mania. Psychiatry Res 2005;139:263-267.

29 Celik Y, Erdogan E, Tuglu C, Utku U: Poststroke mania in late life due to right temporoparietal infarction. Psychiatry Clin Neurosci 2004;58:446-447.

30 Huffman J, Stern TA: Acute psychiatric manifestations of stroke: a clinical case conference. Psychosomatics 2003;44:65-75.

- 31 Gafoor R, O'Keane V: Three case reports of secondary mania: evidence supporting a right frontotemporal locus. Eur Psychiatry 2003;18:32-33.

32 Colenda CC: Mania in late life. The challenges of treating older adults. Geriatrics 2002; $57: 50,53-54$.
33 Benke T, Kurzthaler I, Schmidauer C, Moncayo R, Donnemiller E: Mania caused by a diencephalic lesion. Neuropsychologia 2002; 40:245-252.

34 Inzelberg R, Nisipeanu P, Joel D, Sarkantyus M, Carasso RL: Acute mania and hemichorea. Clin Neuropharmacol 2001;24:300-303.

35 Franco K, Chughtai H: Steroid-induced mania in poststroke patient involving the right basal ganglion and right frontal region. Psychosomatics 2000;41:446-447.

36 Leibson E: Anosognosia and mania associated with right thalamic haemorrhage. J Neurol Neurosurg Psychiatry 2000;68:107108.

37 De León OA, Furmaga KM, Kaltsounis J: Mirtazapine-induced mania in a case of post-stroke depression. J Neuropsychiatry Clin Neurosci 1999;11:115-116.

38 Börnke C, Postert T, Przuntek H, Büttner T Acute mania due to a right hemisphere infarction. Eur J Neurol 1998;5:407-409.

39 Kulisevsky J, Berthier ML: A new case of fluoxetine-induced mania in post-stroke depression. Clin Neuropharmacol 1997;20: 180-181.

40 Trillet M, Vighetto A, Croisile B, Charles N, Aimard G: Hemiballismus with logorrhea and thymo-affective disinhibition caused by hematoma of the left subthalamic nucleus. Rev Neurol (Paris) 1995;151:416-419.

41 Kulisevsky J, Avila A, Berthier ML: Bipolar affective disorder and unilateral parkinsonism after a brainstem infarction. Mov Disord 1995; 10:799-802.

42 Tohen M, Shulman KI, Satlin A: First-episode mania in late life. Am J Psychiatry 1994; 151:130-132.

43 Kumar KR, Kuruvilla K: Secondary mania following stroke. Indian J Psychiatry 1994; 36:33.

44 Berthier ML, Kulisevsky J: Fluoxetine-induced mania in a patient with post-stroke depression. Br J Psychiatry 1993;163:698699.

45 Turecki G, Mari Jde J, Del Porto JA: Bipolar disorder following a left basal-ganglia stroke. Br J Psychiatry 1993;163:690.

46 Kulisevsky J, Berthier ML, Pujol J: Hemiballismus and secondary mania following a right thalamic infarction. Neurology 1993 43:1422-1424.

47 Berthier ML: Post-stroke rapid cycling bipolar affective disorder. Br J Psychiatry 1992; 160:283.

48 Blackwell MJ: Rapid-cycling manic-depressive illness following subarachnoid haemorrhage. Br J Psychiatry 1991;159:279-280.

49 Fawcett RG: Cerebral infarct presenting as mania. J Clin Psychiatry 1991;52:352-353.

50 Snowdon J: A retrospective case-note study of bipolar disorder in old age. Br J Psychiatry 1991;158:485-490.

51 Drake ME, Pakalnis A, Phillips B: Secondary mania after ventral pontine infarction. I Neuropsychiatry Clin Neurosci 1990;2:322325.
52 Starkstein SE, Mayberg HS, Berthier ML, Fedoroff P, Price TR, Dannals RF, Wagner HN, Leiguarda R, Robinson RG: Mania after brain injury: neuroradiological and metabolic findings. Ann Neurol 1990;27:652-659.

53 Danel T, Comayras S, Goudemand M, et al: Troubles de l' humeur et infarcts de l'hémisphère droit. Encephale 1989;15:549553.

54 Mendez MF, Adams NL, Lewandowski KS: Neurobehavioral changes associated with caudate lesions. Neurology 1989;39:349354

55 Stone K: Mania in the elderly. Br J Psychiatry 1989;155:220-224

56 Goldschmidt TJ, Burch EA, Gutnisky G: Secondary mania from cerebral embolization with nonfocal neurologic findings. South Med J 1988;81:1309-1311.

57 Bogousslavsky J, Ferrazzini M, Regli F, Assal G, Tanabe H, Delaloye-Bischof A: Manic delirium and frontal-like syndrome with paramedian infarction of the right thalamus. J Neurol Neurosurg Psychiatry 1988;51:116119 .

58 Cohen MR, Niska RW: Localized right cerebral hemisphere dysfunction and recurrent mania. Am J Psychiatry 1980;137:847-848.

59 Shulman K, Post F: Bipolar affective disorder in old age. Br J Psychiatry 1980;136:26-32.

60 Rosenbaum AH, Barry MJ Jr: Positive therapeutic response to lithium in hypomania secondary to organic brain syndrome. Am J Psychiatry 1975;132:1072-1073.

61 Caeiro L, Ferro JM, Albuquerque R, Figueira ML: Mania no AVC agudo. Sinapse 2002;2: 90.

62 de Toledo Ferraz Alves TC, Ferreira LK, Busatto GF: Vascular diseases and old age mental disorders: an update of neuroimaging findings. Curr Opin Psychiatry 2010;23: 491-497.

63 Marijnissen RM, Bakker M, Stek ML: First manic episode in the elderly - Consider a subdural haematoma due to head trauma as cause. Ned Tijdschr Geneeskd 2010; 154:A1235

64 Vasudev A, Thomas A: 'Bipolar disorder' in the elderly: what's in a name? Maturitas 2010; 66:231-235.

65 Amaladoss A, Le Claire JK: Late onset mania in the elderly. Int J Geriatr Psychiatry 2010; 25:870-872.

66 Bobo WV, Murphy MJ, Heckers SH: Recurring episodes of Bell's mania after cerebrovascular accident. Psychosomatics 2009;50: 285-288.

67 Etches SM, Schmidt M, Alda M, Hajek T, Kahn DA: Resolution of bipolar II and panic disorders following subarachnoid hemorrhage. J Psychiatr Pract 2009;15:145-149.

68 Newcomer JW: Comparing the safety and efficacy of atypical antipsychotics in psychiatric patients with comorbid medical illnesses. J Clin Psychiatry 2009;70:30-36. 
-69 Braun CM, Daigneault R, Gaudelet S, Guimond A: Diagnostic and Statistical Manual of Mental Disorders, Fourth Edition symptoms of mania: which one(s) result(s) more often from right than left hemisphere lesions? Compr Psychiatry 2008;49:441-459.

70 Newcomer JW: Introduction: cardiovascular disease and metabolic risk factors in patients with mental illness. CNS Spectr 2008;13(6 Suppl 10):1-14.

-71 Baldwin RC: Recent understandings in geriatric affective disorder. Curr Opin Psychiatry 2007;20:539-543.

-72 Zanetti MV, Cordeiro Q, Busatto GF: Late onset bipolar disorder associated with white matter hyperintensities: a pathophysiological hypothesis. Progr Neuropsychopharmacol Biol Psychiatry 2007;31:551-556.

-73 Woo BK, Sevilla CCJ: New-onset paranoia and bipolar disorder associated with intracranial aneurysm. Neuropsychiatry Clin Neurosci 2007;19:489-490.

-74 Gruber J, Lemoine JN, Knight RT, Harvey AG: Positive mood and sleep disturbance in acquired mania following temporal lobe damage. Brain Injury 2007;21:1209-1215.

-75 Subramaniam H, Dennis MS, Byrne EJ: The role of vascular risk factors in late onset bipolar disorder. Int J Geriatr Psychiatry 2007; 22:733-737.

-76 Lin HC, Tsai SY, Lee HC: Increased risk of developing stroke among patients with bipolar disorder after an acute mood episode: a six-year follow-up study. J Affect Disord 2007;100:49-54.

-77 Donovan AL, Freudenreich O: Resolution of late-onset hypomania after repair of carotid artery stenosis: a case of vascular hypomania. J Clin Psychiatry 2007;68:798

78 Wijeratne C, Malhi GS: Vascular mania: an old concept in danger of sclerosing? A clinical overview. Acta Psychiatr Scand Suppl 2007;116(suppl 434):35-40.

79 Roselló PA, Tordera TV: Bipolar disorder and subdural hematoma: difficulties for a dual diagnosis. A case report. An Psiquiatr 2007;23:356-358

80 Chemerinski E, Levine SR: Neuropsychiatric disorders following vascular brain injury. Mt Sinai J Med 2006;73:1006-1014.

81 Senturk V, Bilgic A, Atbasoglu EC: A case of probable bipolar VI disorder? J Clin Psychiatry 2006;67:1309-1310.

82 Watanabe Y, Shioiri T, Kuwabara H, Someya T: Mania after vascular dementia in a patient with bipolar II disorder. Psychiatry Clin Neurosci 2006;60:117-118.

83 Baune BT, Adrian I, Arolt V, Berger K: Associations between major depression, bipolar disorders, dysthymia and cardiovascular diseases in the general adult population. Psychother Psychosom 2006;75:319-326.
84 Kannan K, Tan SMK, Pillai SK, Sinniah D, Raymond AA, Hamzaini AH, Loh SF, Ismail WS, Swami V, Ruzyanie N: Bipolar mood disorder secondary to mitochondrial encephalomyopathy, lactic acidosis and strokelike episodes (MELAS): a case report. Hong Kong J Psychiatry 2006;16:150-153.

$>85$ de Filippis S, Salvatori E, Bozzao A, Fantozzi LM, Martelletti P: Migraine with aura, bipolar depression, ACM aneurysm. A case report. J Headache Pain 2005;6:9396.

86 Heinrich TW, Junig JT: Recurrent mania associated with repeated brain injury. Gen Hosp Psychiatry 2004;26:490-492.

87 Nilsson FM, Kessing LV: Increased risk of developing stroke for patients with major affective disorder - A registry study. Eur Arch Psychiatry Clin Neurosci 2004;254: 387-391.

88 Robinson RG: Poststroke depression: prevalence, diagnosis, treatment, and disease progression. Biol Psychiatry 2003;54:376387.

89 Jain S, Gibson RH, Guedet PJ, Lehrmann JA, Tsao CI: Aspiration pneumonia as a complication of severe mania. Gen Hosp Psychiatry 2003;25:136-137.

$\checkmark 90$ Sasaki M: Organic mixed affective disorder. Ryoikibetsu Shokogun Shirizu 2003; 40:180-183.

-91 Suárez-Richards M, Fournes O: Erotomania preceding an aneurysmal subarachnid haemorrhage: is there an association? J Affect Disord 2002;70:333-336.

92 Okamoto K, Miwa H, Kamiyoshi S, Takagi R, Maeshima S, Kondo T: Recurrent unipolar depression with 48-hour cycle and the state - Dependent abnormal involuntary movements following right thalamic haemorrhage. No To Shinkei 2002;54:595-599.

$>93$ Varga D: Neuropsychiatric complications after stroke. Ideggyogy Sz 2002;55:128136.

-94 Cassidy F, Carroll BJ: Vascular risk factors in late onset mania. Psychol Med 2002;32: 359-362.

$\$ 95$ Perez J, Tardito D: The interface between depression and cerebrovascular disease Some hope but no hype. Clin Exp Hypertens 2002;24:639-646.

$\checkmark 96$ Hirose T: Comorbidity in depressive disorders. Seishin Shinkeigaku Zasshi 2001;103 1046-1054.

97 Novak-Grubic V, Tavcar R, Davis JM: Lithium intoxication secondary to unrecognized pontine haemorrhage. Acta Psychiatr Scand 2001;103:400-401.

$\$ 98$ Kumar R: Lesion location in mania following stroke. Aust NZ J Psychiatry 2000;34: 170

99 Mendez MF: Mania in neurologic disorders. Curr Psychiatry Rep 2000;2:440-445.

$\checkmark 100$ Taha S, Diaz A, Compeyre S, Cabal P, Comoy J, Leriche B: Krouamania causing an acute subdural hematoma of arterial origin. Rev Neurol (Paris) 1999;155:1079-1081.
101 Shulman KI, Herrmann N: Bipolar disorder in old age. Can Fam Physician 1999;45: 1229-1237.

102 Braun CM, Larocque C, Daigneault S, Montour-Proulx I: Mania, pseudomania, depression, and pseudo-depression resulting from focal unilateral cortical lesions. Neuropsychiatry Neuropsychol Behav Neurol 1999;12:35-51.

103 Shulman KI, Herrmann N: The nature and management of mania in old age. Psychiatr Clin North Am 1999;22:649.

104 Bakchine S: Post-lesional depression and mania. Rev Neuropsychol 1998;8:691-726.

105 Anderson CA, Camp J, Filley CM: Erotomania after aneurysmal subarachnoid hemorrhage: case report and literature review. J Neuropsychiatry Clin Neurosci 1998;10:330-337.

106 Kumar SK, Mahr G: CADASIL presenting as bipolar disorder. Psychosomatics 1997; 38:397-398.

107 Ghika-Schmid F, Bogousslavsky J: Affective disorders following stroke. J Eur Neurol 1997;38:75-81.

108 Fukatsu R, Fujii T, Yamadori A, Nagasawa H, Sakurai Y: Persisting childish behavior after bilateral thalamic infarcts. Eur Neurol 1997;37:230-235.

109 Robinson RG: Neuropsychiatric consequences of stroke. Annu Rev Med 1997;48: 217-229.

110 Robinson RG, De Carvalho ML, Paradiso S: Post-stroke neuropsychiatric problems Diagnosis, pathophysiology and treatment. J Bras Psiquiatr 1997;46:527-534.

111 Berthier ML, Kulisevsky J, Gironell A, Fernández Benitez JA: Post-stroke bipolar affective disorder: clinical subtypes, concurrent movement disorders, and anatomical correlates. J Neuropsychiatry Clin Neurosci 1996;8:160-167.

112 Verdoux H, Bourgeois M: Manies secondaires à des pathologies organiques cérébrales. Ann Méd Psychol 1995;153:161-168.

113 Tatter SB, Ogilvy CS: Recurrent manic episode 10 years after arteriovenous malformation resection. J Clin Psychiatry 1995;56: 83

114 Evans DL, Byerly MJ, Greer RA: Secondary mania: diagnosis and treatment. J Clin Psychiatry 1995;56(suppl 3):31-37.

115 Fujikawa T, Yamawaki S, Touhouda Y: Silent cerebral infarctions in patients with late-onset mania. Stroke 1995;26:946-949.

116 Daum I, Ackermann H: Frontal-type memory impairment associated with thalamic damage. Int J Neurosci 1994;77:187-198.

117 Friedman EH, Kulisevsky J, Pujol J, Berthier ML: Ballismus and mania. Neurology 1994;44:578

118 McGilchrist I, Goldstein LH, Jadresic D, Fenwick P: Thalamo-frontal psychosis. Br J Psychiatry 1993;163:113-115. 
-119 Gnam W, Flint AJ: New onset rapid cycling bipolar disorder in an 87 year old woman. Can J Psychiatry 1993;38:324-326.

120 Lehembre P, Graux P: Athymormia, arithmomania or stercoral compulsion in multiple infarcts of the corpus striatum. Ann Med Psychol (Paris) 1992;150:699-701.

-121 Miller BL, Mena I, Giombetti R, Villanueva-Meyer J, Djenderedjian AH: Neuropsychiatric effects of cocaine: SPECT measurements. J Addict Dis 1992;11:47-58.

$\checkmark 122$ House A, Dennis M, Mogridge L, Warlow C, Hawton K, Jones L: Mood disorders in the year after first stroke. Br J Psychiatry 1991;158:83-92.

123 Moskowitz AS, Altshuler L: Increased sensitivity to lithium-induced neurotoxicity after stroke: a case report. J Clin Psychopharmacol 1991;11:272-273.

124 Berrios GE, Bakshi N: Manic and depressive symptoms in the elderly: their relationships to treatment outcome, cognition and motor symptoms. Psychopathology 1991; 24:31-38.

125 Beckson M, Cummings JL: Neuropsychiatric aspects of stroke. Int J Psychiatry Med 1991;21:1-15.

-126 Wilson D, McLaughlin T: Cerebrovascular disease and secondary mania. Gen Hosp Psychiatry 1990;12:271-275.

-127 Berthier ML, Starkstein SE, Robinson RG, Leiguarda R: Limbic lesions in a patient with recurrent mania. J Neuropsychiatry Clin Neurosci 1990;2:235-236.
128 Robinson RG, Starkstein SE: Current research in affective disorders following stroke. J Neuropsychiatry Clin Neurosci 1990;2:1-14.

129 Feinberg WM, Rapcsak SZ: 'Peduncular hallucinosis' following paramedian thalamic infarction. Neurology 1989;39:15351536.

130 Bakchine S, Lacomblez L, Benoit N, Parisot D, Chain F, Lhermitte F: Manic-like state after bilateral orbitofrontal and right temporoparietal injury: efficacy of clonidine. Neurology 1989;39:777-781.

131 Starkstein SE, Berthier ML, Lylyk PL, Casasco A, Robinson RG, Leiguarda R: Emotional behavior after a Wada test in a patient with secondary mania. J Neuropsychiatry Clin Neurosci 1989;1:408-412.

132 Davison K: Neuropsychiatry of localized brain disorders and encephalopathies. Curr Opin Psychiatry 1989;2:76-83.

133 Gross RA, Herridge P: A manic-like illness associated with right frontal arteriovenous malformation. J Clin Psychiatry 1988;49: 119-120.

134 Gentilini M, De Renzi E, Crisi G: Bilateral paramedian thalamic artery infarcts: report of eight cases. J Neurol Neurosurg Psychiatry 1987;50:900-909.

135 Kwentus JA, Hart RP: Normal pressure hydrocephalus presenting as mania. J Nerv Ment Dis 1987;175:500-502.

136 Caplan LR, Kelly M, Kase CS, Hier DB, White JL, Tatemichi T, Mohr J, Price T, Wolf P: Infarcts of the inferior division of the right middle cerebral artery: mirror image of Wernicke's aphasia. Neurology 1986; 36:1015-1020.
137 Kahn D, Sackeim H, Malitz S: Evaluating lesion activity in manic patients. Am J Psychiatry 1984;141:1016.

138 Scherrer P: The case of Marie-Louise N... A manic-depressive patient confined to a general hospital after a stroke followed by aphasia. Ann Med Psychol (Paris) 1982;140: 530-539.

139 Whitlock FA: The neurology of affective disorder and suicide. Aust NZ J Psychiatry 1982;16:1-12.

140 Scherrer P, Houillon M: A manic-depressive patient isolated in a general hospital after an ictus followed by aphasia. Ann Med Psychol 1982;140:530-539.

141 Trimble MR, Cummings JL: Neuropsychiatric disturbances following brainstem lesions. Br J Psychiatry 1981;138:56-59.

142 Bourgeois M, Campagne A: Manic-depressive and Garcin's syndrome. Ann Med Psychol (Paris) 1967;125(suppl 2):451-460.

143 van der Lugt PJ, de Visser AP: Two patients with a vital expansive syndrome following a cerebrovascular accident. Psychiatr Neurol Neurochir 1967;70:349-359.

144 Symons HS: Mania due to cerebral fat embolism following fracture of the tibia. Med J Aust 1960;47:980-981.

145 Dunne JW, Leedman PJ, Edis RH: Inobvious stroke: a cause of delirium and dementia. Aust NZ J Med 1986;16:771-778.

146 McDonald WM: Epidemiology, etiology, and treatment of geriatric mania. J Clin Psychiatry 2000;61(suppl 13):3-11. 